\title{
Immunohistochemical Localization of V2 Vasopressin Receptor along the Nephron and Functional Role of Luminal V2 Receptor in Terminal Inner Medullary Collecting Ducts
}

\author{
Hiroshi Nonoguchi, Akira Owada, ${ }^{\star}$ Naoto Kobayashi, ${ }^{\ddagger}$ Masanobu Takayama, ${ }^{\star}$ Yoshio Terada, ${ }^{\star}$ Jun Koike, ${ }^{\star}$ \\ Kazutomo Ujile, ${ }^{*}$ Fumiaki Marumo, ${ }^{*}$ Tatsuo Sakai, ${ }^{\ddagger}$ and Kimio Tomita \\ Third Department of Internal Medicine, Kumamoto University School of Medicine, 1-1-1 Honjo, Kumamoto, Kumamoto 860, Japan; \\ * Second Department of Internal Medicine, Tokyo Medical \& Dental University, 1-5-45 Yushima, Bunkyo-ku, Tokyo 113, Japan; and \\ ${ }^{\ddagger}$ First Department of Anatomy, Juntendo University School of Medicine, 2-1-1 Hongo, Bunkyo-ku, Tokyo 113, Japan
}

\begin{abstract}
We investigated immunohistochemical localization of $\mathrm{V} 2$ vasopressin receptor along the nephron using a specific polyclonal antibody. Staining was observed in some of thick ascending limbs and all of principal and inner medullary collecting duct (IMCD) cells. Not only basolateral but also luminal membrane was stained in collecting ducts, especially in terminal IMCD (tIMCD).

To learn the functional role of luminal $\mathrm{V} 2$ receptor in tIMCD, we studied the luminal effects of arginine vasopressin (AVP) on osmotic water permeability (Pf), urea permeability (Pu), and cAMP accumulation using isolated perfused rat tIMCD. In the absence of bath AVP, luminal AVP caused a small increase in cAMP accumulation, $P f$ and $P u$, confirming the presence of $\mathrm{V} 2$ receptor in the lumen of tIMCD. In contrast, luminal AVP inhibited Pf and Pu by 30-65\% in the presence of bath AVP by decreasing cAMP accumulation via V1a or oxytocin receptors and by an unknown mechanism via $\mathrm{V} 2$ receptors in the luminal membrane of tIMCD.

These data show that $\mathrm{V} 2$ receptors are localized not only in the basolateral membrane but also in the luminal membrane of the distal nephron. Luminal AVP acts as a negative feedback system upon the basolateral action of AVP in tIMCD. (J. Clin. Invest. 1995. 96:1768-1778.) Key words: V1a receptor • oxytocin $\cdot$ cyclic AMP • urine concentration
\end{abstract}

\section{Introduction}

The main role of the kidney is to maintain the body fluid homeostasis by producing concentrated and diluted urine (1). Several

Portions of this study were presented at the 24th, 25th, 26th, and 27th Annual Meetings of the American Society of Nephrology in Baltimore, MD in November 1991 and 1992, in Boston, MA, November 1993, and in Orlando, FL October 1994, and have appeared in abstract form ( $J$. Am. Soc. Nephrol. 2:276, 3:797, 4:857, and 5:276).

Address correspondence to Hiroshi Nonoguchi, Third Department of Internal Medicine, Kumamoto University School of Medicine, 1-11 Honjo, Kumamoto, Kumamoto 860, Japan. Phone:81-96-373-5160; FAX:81-96-366-8458.

Received for publication 21 October 1994 and accepted in revised form 10 July 1995.

J. Clin. Invest.

(C) The American Society for Clinical Investigation, Inc.

0021-9738/95/10/1768/11 \$2.00

Volume 96, October 1995, 1768-1778 hormones, i.e., arginine vasopressin (AVP), ${ }^{1}$ atrial natriuretic peptide, parathyroid hormone, calcitonin, glucagon, mineralocorticoids, and glucocorticoids, are known to influence renal ion and water transport. Among these hormones, AVP is the key hormone responsible for producing concentrated urine, and it is excreted in high concentrations during antidiuresis.

At least two types of AVP receptors are known in the kidney: V1a and V2 receptors (2). V1a receptors are localized mainly in the vascular system and glomeruli and participate in the vasopressor effect of AVP (3). The antidiuretic action of AVP is mediated through adenylate cyclase-coupled V2 receptors, and cAMP is the second messenger for the antidiuretic action of AVP (4). AVP-sensitive adenylate cyclase is widely distributed in the nephron: from the medullary thick ascending limbs to the collecting ducts (5). V2 receptors are believed to be located only in the basolateral membrane. Recently, AVP has been shown to act at the luminal membrane in the cortical collecting duct (CCD), probably via luminal V1a receptors (6). This finding gave physiological meaning to large excretions of AVP into the urine, especially in antidiuresis. The presence of $\mathrm{V} 1 \mathrm{a}$ receptors in CCD suggests the possibility that luminal V1a or $\mathrm{V} 2$ receptors could exist in other nephron segments, thus indicating that there is a physiological role for the high concentrations of urinary AVP during antidiuresis (7).

Recently, cDNAs of V2 and V1a vasopressin receptor were cloned $(8,9)$. In the present study, we investigated the immunohistochemical localization of V2 vasopressin receptor along the nephron using specific polyclonal antibody. Our data showed the presence of V2 receptor both in the luminal and basolateral membrane of distal nephron, especially heavily in the terminal inner medullary collecting duct (tIMCD).

The tIMCD is the final segment of the nephron and is an important segment for urine concentration. The IMCD has V2 receptors as well as receptors for atrial natriuretic peptide (10). Its water and urea permeabilities are quite high, especially in the presence of AVP (11). Thus, as the second part of our study, we investigated the effects of luminal and basolateral AVP in the tIMCD on water and urea permeability and cAMP

1. Abbreviations used in this paper: AVP, arginine vasopressin; CAL, cortical thick ascending limb; CCD, cortical collecting duct; dDAVP, [deamino-Cys ${ }^{1}$, D-Arg ${ }^{8}$ ]-vasopressin; GN-OVT, desGly-NH ${ }_{2}$ $\mathrm{d}\left(\mathrm{CH}_{2}\right)^{5}\left[\mathrm{Tyr}(\mathrm{Me})^{2}, \mathrm{Thr}^{4}\right]$-oxyvasotocin; IBMX, 3-isobutyl-1-methylxanthine; IMCD, inner medullary collecting duct; MAL, medullary thick ascending limb; OMCD, outer medullary collecting duct; Pf, osmotic water permeability; PTEtV-AVP, $\left[\mathrm{Pmp}^{1}, \operatorname{Tyr}(\mathrm{Et})^{2}, \mathrm{Val}^{4}, \mathrm{Arg}^{8}\right]$-vasopressin; PTMe-AVP, [Pmp $\left.{ }^{1}, \operatorname{Tyr}(\mathrm{Me})^{2}, \mathrm{Arg}^{8}\right]$-vasopressin; $\mathrm{Pu}$, urea permeability; tg-OXT, [ $\left.\mathrm{Thr}^{4}, \mathrm{Gly}^{7}\right]$-oxytocin; tIMCD, terminal IMCD. 
accumulation to ascertain the functional role of $\mathrm{V} 2$ receptors in the luminal and basolateral membrane of tIMCD.

\section{Methods}

Materials. AVP, [deamino-Cys ${ }^{1}$, D-Arg $^{8}$ ]-vasopressin (dD-AVP) (V2 agonist), $\left[\mathrm{Pmp}^{1}, \mathrm{Tyr}(\mathrm{Et})^{2}, \mathrm{Val}^{4}, \mathrm{Arg}^{8}\right]$-vasopressin (PTEtV-AVP) (V2 antagonist) (12), oxytocin, [ $\left.\mathrm{Thr}^{4}, \mathrm{Gly}^{7}\right]$-oxytocin (tg-OXT) (oxytocin agonist) (13), and collagenase were obtained from Sigma Chemical Co. (St. Louis, MO). $\left[\mathrm{Pmp}^{1}, \operatorname{Tyr}(\mathrm{Me})^{2}, \operatorname{Arg}^{8}\right]$-vasopressin (PTMe-AVP) (V1a antagonist) (14) was purchased from Peptide Institute (Osaka, Japan). desGly- $\mathrm{NH}_{2}-\mathrm{d}\left(\mathrm{CH}_{2}\right)^{5}\left[\mathrm{Tyr}(\mathrm{Me})^{2}, \mathrm{Thr}^{4}\right]$-oxyvasotocin (GN-OVT) (oxytocin antagonist) (15) was a kind gift from Dr Maurice Manning (Medical College of Ohio, Toledo, OH). OPC 21268 (V1a antagonist) (16) and OPC 31260 (V2 antagonist) (17) were gifts from Otsuka Pharmaceutical Co. (Osaka, Japan).

A polyclonal antibody. We raised a polyclonal antibody (named anti-N-3 peptide) against the synthetic peptide corresponding to the intracellular loop between the fifth and sixth transmembrane domains (PSERAGTPQRAPDRSPSE) of rat V2 receptor (9). The peptide was chosen because of its high hydrophilicity from the hydropathy plot. The homology of the peptide was checked by the DNAsis (Hitachi Software Engineering Co., Tokyo, Japan). The peptide was synthesized with cysteine for its $\mathrm{NH}_{2}$-terminal (purity of $99.0 \%$ by HPLC; Peptide Institute, Osaka, Japan). After taking preimmune serum, rabbit antisera was raised against the peptide conjugated to Keyhole Limpet Hemocyanin (Imject Activated Immunogen Conjugation Kits; Pierce, Rockford, IL). Male New Zealand White rabbits (1.5-2.0 kg, from Japan Laboratory Animals, Tokyo, Japan) were immunized with $0.5 \mathrm{ml}$ of conjugates ( $0.4 \mathrm{mg}$ of the peptide) emulsified with Freund's complete adjuvant. Afterward, conjugates emulsified with Freund's incomplete adjuvan were injected for boosts every 2 wk until the antibody was obtained. After each boost, blood was collected from an ear vein and the antibody response was measured by ELISA. When ELISA yielded a high value, the specificity of the antisera was checked by Western blot analysis.

SDS-PAGE and Western blot analysis. IgG fraction of the antisera was affinity purified from sera of the immunized rabbit using protein G (MAb Trap GII Kit; Pharmacia Diagnostics AB, Uppsala, Sweden) or affinity column prepared from N-3 peptide. The peptide was linked to the solid phase via a sulphydryl linkage using an Immuno Pure Immobilization kit \#2 (Pierce) following the manufacturer's instructions. Binding of the antibody to the column and elution ( $\mathrm{pH} 2.8$ glycine) were done exactly as described by the instruction manual. The final IgG concentration was $0.347 \mathrm{mg} / \mathrm{ml}$.

Membrane fraction was prepared from inner medulla of rat kidneys. After dissecting both kidneys, inner medulla was cut out, minced with a razor blade, and homogenized with five strokes at $1,000 \mathrm{rpm}$ using a glass homogenizer at $4^{\circ} \mathrm{C}$. Supernatant was collected after centrifugation at 7,600 rpm for $15 \mathrm{~min}$ at $4^{\circ} \mathrm{C}$. Membrane fraction of inner medulla was collected by centrifugation of the above supernatant at $21,500 \mathrm{rpm}$ for $30 \mathrm{~min}$ at $4^{\circ} \mathrm{C}$. After measuring protein content, the membrane fraction was stored at $-80^{\circ} \mathrm{C}$ until usage. The composition of the lysis buffer was (mM): $0.5 \mathrm{Na}_{3} \mathrm{VO}_{4}, 1$ EDTA, 5 EGTA, 2 DL-dithiothreitol (DTT), 1 PMSF, $10 \mu \mathrm{g} / \mathrm{ml}$ aprotinine, $10 \mu \mathrm{g} / \mathrm{ml}$ leupeptine, $5 \beta$-glycerophosphate, and 20 Hepes (pH 7.4).

In some experiments, membrane fraction of rat inner medulla was treated with recombinant $N$-glycanase ( $N$-glycosidase F; Boehringer Mannheim, Mannheim, Germany) before electrophoresis. Membrane fractions were denatured in $1 \%$ SDS solution and then solubilized in $24 \mathrm{mM}$ EDTA, $1 \%$ NP-40, $2 \% \beta$-mercaptoethanol, $0.1 \%$ SDS, and 62.5 $\mathrm{mM}$ Tris- $\mathrm{HCl}(\mathrm{pH} 8.4$ ) containing $0,6,40$, or $72 \mathrm{U} / \mathrm{ml}$ of $N$-glycanase in $100 \mathrm{mM}$ sodium phosphate buffer for $26 \mathrm{~h}$ at $37^{\circ} \mathrm{C}(18)$.

SDS-PAGE was performed using the buffers described previously (19) and $1 \times 84 \times 90 \mathrm{~mm}$ gradient gel of $4-20 \%$ of acrylamide. Membrane fraction was mixed with sample buffer (final concentration; $10 \%$ glycerol, 3\% SDS, $5 \% \beta$-mercaptoethanol, $65 \mathrm{mM}$ DTT, $0.005 \%$ bromophenol blue, $62.5 \mathrm{mM}$ Tric- $\mathrm{HCl}[\mathrm{pH} 6.8]$. When membrane frac- a

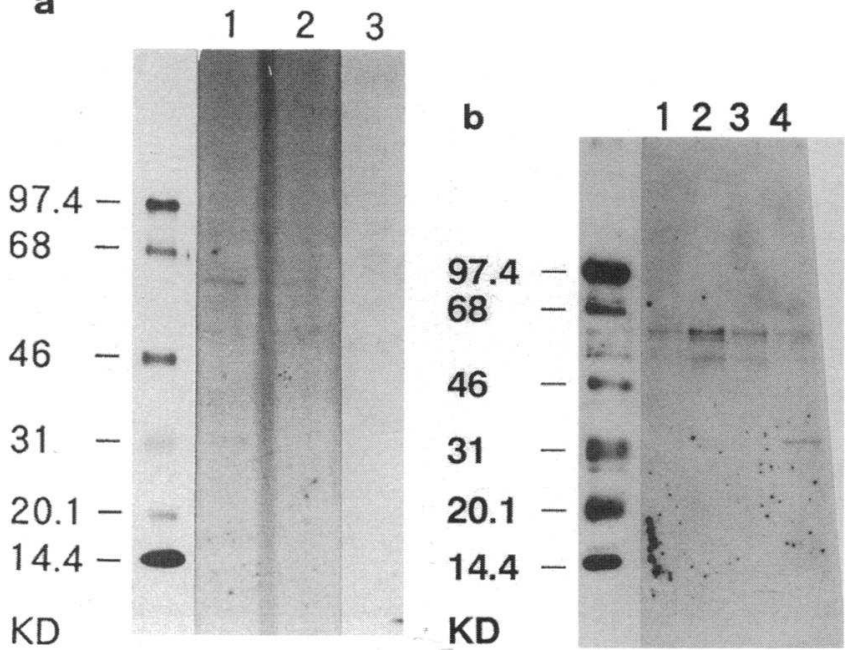

Figure 1. Immunoblot analysis of the antibody. (a) $30 \mu \mathrm{g}$ of the membrane protein from rat inner medulla was loaded in each lane. The anti$\mathrm{N}-3$ peptide (IgG fraction) was used at dilution of 1:10,000. (lane I) Anti-N-3 peptide recognized a single band at $62 \mathrm{kD}$; (lane 2) This band was absorbed by addition of the N-3 peptide to the anti-N-3 peptide; (lane 3 ) No band was detected by the preimmune serum $(1: 5,000)$. (b) $13.2 \mu \mathrm{g}$ of the membrane fraction from rat inner medulla was loaded in each lane after the digestion with $\mathrm{N}$-glycanase. The concentrations of $N$-glycanase was 0 (lane 1 ), 6 (lane 2), 40 (lane 3 ), and $72 \mathrm{U} / \mathrm{ml}$ (lane 4). The anti-N-3 peptide (IgG fraction) was used at dilution of 1:2,500. There was a shift in molecular weight from 62 to 36 in higher concentrations of $N$-glycanase (lane 4 ).

tion was solubilized with $\mathrm{N}$-glycanase, the concentration of SDS was reduced to $2.3 \%$. 6-40 $\mu \mathrm{g}$ of the membrane protein was loaded in each lane. After denaturing the sample in the boiling water for $5 \mathrm{~min}$, electrophoresis was performed in the presence of running buffer ( 25 $\mathrm{mM}$ Tris, $192 \mathrm{mM}$ glycine, $0.1 \%$ SDS ). The antigen was then transferred from the gel onto the nitrocellulose membrane electrophoretically. After blocking the membrane with 5\% skim milk in Tris-buffered saline with $0.1 \%$ Tween 20 (TBS-T) buffer, the antibody in 5\% skim milk in TBS-T buffer was reacted with the membrane overnight at $4^{\circ} \mathrm{C}$. Secondary antibody (horseradish peroxidase-linked anti-rabbit immunoglobulin) was then reacted with the membrane for $1 \mathrm{~h}$ at room temperature. Immunoblots were visualized with enhanced chemiluminescence (Amersham Corp. Arlington Heights, IL).

Immunohistochemical study. To examine the localization of V2 receptors in the kidney, kidney slices were made. Rats were injected with pentobarbital ( $5 \mathrm{mg} / 100$ gram body weight) and the left kidney was fixed with $4 \%$ paraformaldehyde in PBS through the abdominal aorta. Kidney was cut into the blocks of cortex, outer medulla, and inner medulla. The blocks were then fixed by immersion in $4 \%$ paraformaldehyde in PBS for $60 \mathrm{~min}, 2 \%$ paraformaldehyde, and $10 \%$ sucrose in PBS for $4 \mathrm{~h}, 15 \%$ sucrose in PBS for $4 \mathrm{~h}$, and $20 \%$ sucrose in PBS for 4-6 h. All solutions were cooled on ice. The blocks were then rapidly frozen in liquid nitrogen.

4- to 5- $\mu \mathrm{m}$ thick sections were cut and mounted on eggwhite-coated slides. The sections were incubated with normal goat serum for $1 \mathrm{~h}$ at room temperature. After rinsing with PBS, the sections were incubated with IgG fraction of rabbit antisera (anti-N-3 peptide, 1:500) or preimmune rabbit serum (1:500) overnight at $4^{\circ} \mathrm{C}$. The sections were then rinsed with PBS and incubated with FITC-conjugated goat-anti-rabbit $\operatorname{IgG~F}\left(\mathrm{ab}^{\prime}\right)_{2}$ (Cappel, Organon Teknika Corp., Durham, NC) for $1 \mathrm{~h}$ at room temperature. The sections were rinsed by PBS with vibration and sealed in a mixture of $10 \%$ PBS and $90 \%$ glycerol containing $0.3 \%$ para-phenylenediamine. The specimens were photographed with a confocal laser scanning microscope (LSM-10; Carl Zeiss Inc., Ober- 

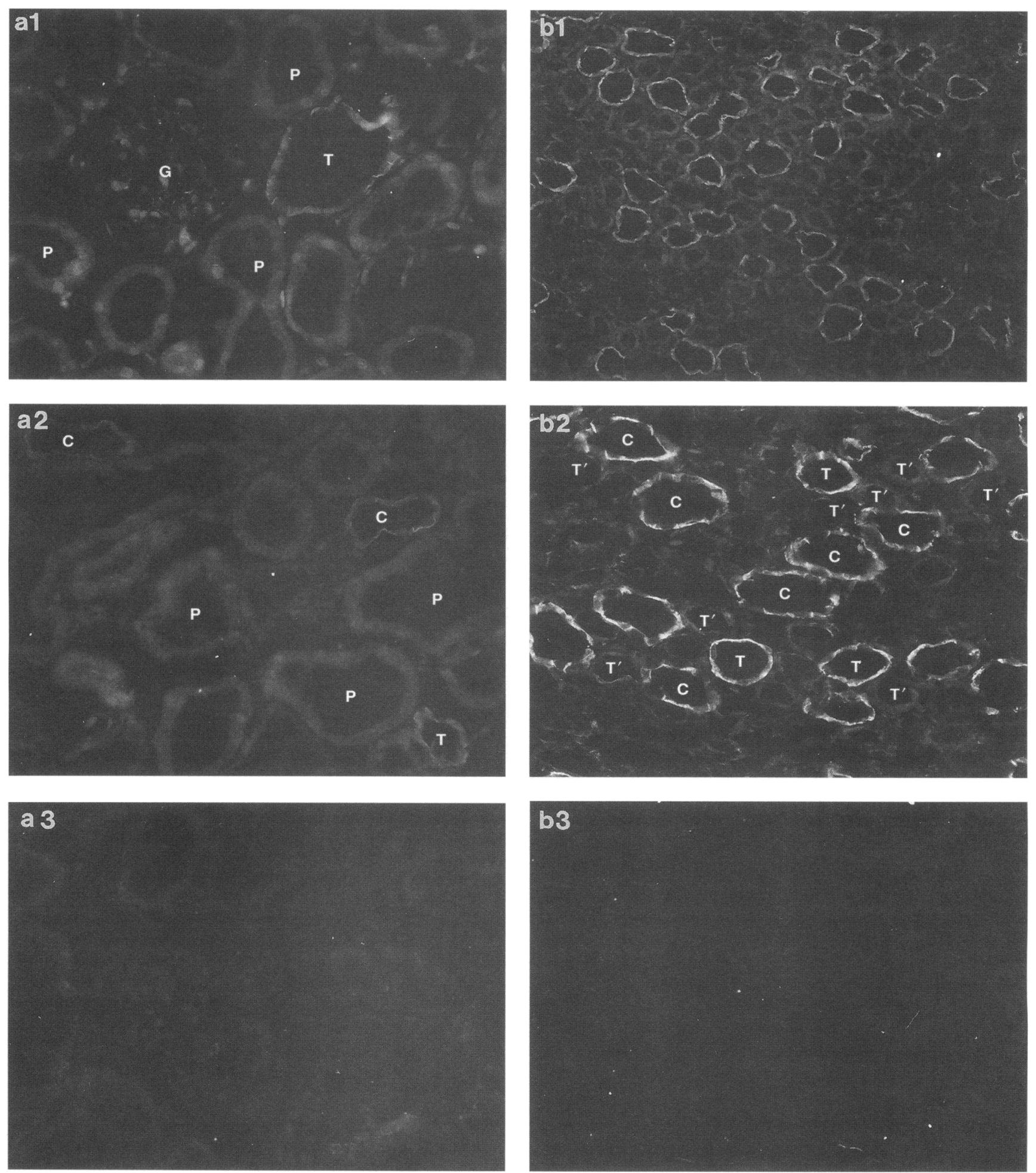

Figure 2. Immunohistochemical localization of $\mathrm{V} 2$ receptors in cortex $(a)$, inner stripe of outer medulla $(b)$, and inner medulla $((c)$ of the rat kidney. Sections of each part of the kidney were incubated with the diluted antisera ( IgG fraction, $\times 500$ ) overnight at $4^{\circ} \mathrm{C}$, and then with FITCconjugated goat-anti-rabbit $\operatorname{IgG~F}\left(\mathrm{ab}^{\prime}\right) 2$ for $1 \mathrm{~h}$ at room temperature. (al) The basolateral membrane of cortical thick ascending limb $(T)$ next to glomurulus $(G)$ was stained. No staining was observed in proximal tubules $(P)$. $(a 2)$ The basolateral membrane of principal cells of $C C D(C)$ and CAL $(T)$ were stained. (a3) There was no staining by preimmune serum (1:500) besides the autofluorescence from proximal tubules. (bl) OMCD and some of MAL were stained. (b2) The larger magnification showed that the basolateral membrane OMCD $(C)$ and some of MAL (T) were stained. The MAL without staining $\left(T^{\prime}\right)$ seems to have thicker cell and smaller lumen than that with staining $(T)$. (b3) No staining was observed with preimmune serum. ( $c 1)$ All of the tIMCD were stained. ( $(2)$ Larger magnification showed the heavy staining in the basolateral membrane and slight staining in the cytoplasm and the luminal membrane. (c3) No staining in IMCD was observed by preimmune serum. 

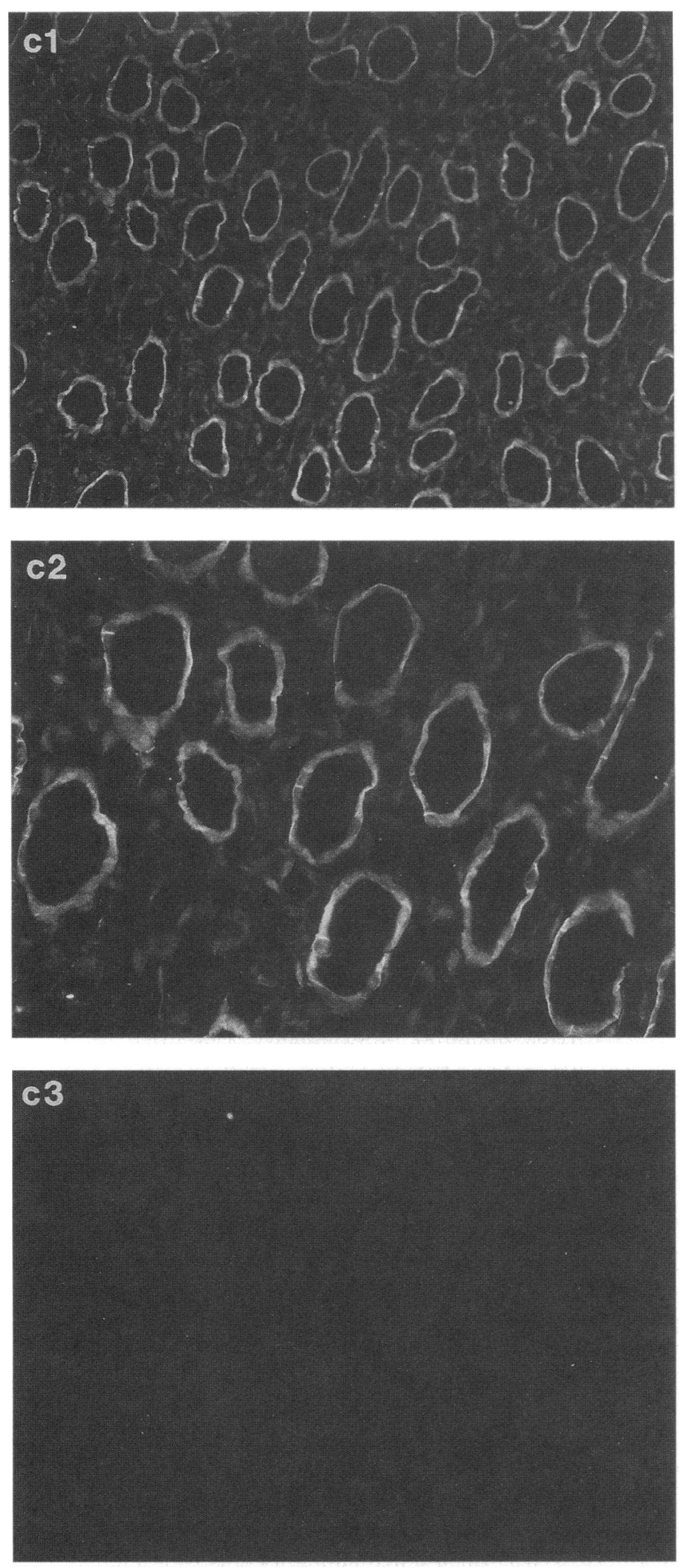

Figure 2 (Continued)

kochen, Germany) or with a conventional fluorescent microscope. Exactly same exposure time was used for the photographs of control and positive studies. The thickness of scanning section using confocal laser scanning microscopy $<1 \mu \mathrm{m}$ (manufacturer's data).

Isolated tubule perfusion study. Terminal IMCD was dissected from the terminal two-thirds of the inner medulla of the kidney from pathogen-free male Sprague Dawley rats weighing 50-100 grams (Japan
Laboratory Animals Inc., Tokyo, Japan), as described previously (11, 20, 21).

The basic solution for the isolated tubule perfusion study (solution A) had the following composition (mM): $118 \mathrm{NaCl}, 25 \mathrm{NaHCO}_{3}, 2.5$ $\mathrm{K}_{2} \mathrm{HPO}_{4}, 1 \mathrm{MgSO}_{4}, 1$ Ca lactate, $2 \mathrm{Na}$ acetate, 5.5 glucose, 5 L-alanine, $2 \mathrm{~L}$-leucine. This solution was continuously aerated with $5 \% \mathrm{CO}_{2}-95 \%$ $\mathrm{O}_{2}$. The composition of the basic solution for the cAMP accumulation study (solution B) was (mM): $130 \mathrm{NaCl}, 5 \mathrm{KCl}, 1 \mathrm{NaH}_{2} \mathrm{PO}_{4}, 1 \mathrm{MgSO}_{4}$, $1 \mathrm{Ca}$ lactate, $2 \mathrm{Na}$ acetate, 5.5 glucose, 5 L-alanine, 2 L-leucine, 10 Hepes; and $\mathrm{pH}$ was adjusted to 7.4 by $\mathrm{NaOH}$.

Osmotic water permeability (Pf) study. Pf was measured as described previously $(11,20,21)$. In brief, Pf was determined by measuring the water flux resulting from $200 \mathrm{mOsm} / \mathrm{kg} \times \mathrm{H}_{2} \mathrm{O}$ bath-to-lumen osmolality gradient. The perfusion and bath solutions were nearly identical to the dissection solution (solution $\mathrm{A}$ ), the only exception being that an additional $106 \mathrm{mM} \mathrm{NaCl}$ that was added to the bath solution. Creatinine was used as the volume marker for the measurement of Pf. Pf was calculated using the equation of Al-Zahid et al. (22).

The creatinine concentrations in perfusate, bath, and collected fluid were measured using a continuous flow ultramicro-colorimeter as described previously (11). According to our previous study (11), we waited $40 \mathrm{~min}$ before starting collections to washout any intrinsic vasopressin responses. Care was taken to avoid collapse of the tubule during perfusate exchanges. Experimental collections were made 10-30 min thereafter.

Urea permeability study. Urea permeability was measured as described previously $(11,20,21)$. In these experiments, the perfusion and bath solutions were nearly identical to the dissection solution (solution A), the only exception being that the bath solution contained $5 \mathrm{mM}$ urea and no raffinose, and that the perfusate contained $5 \mathrm{~mm}$ raffinose and no urea. The urea concentrations in the perfusate, bath, and collected fluid were measured enzymatically using a continuous flow ultramicrofluorometer (11).

Cyclic AMP accumulation study. Cyclic AMP is the second messenger for the V2 action of AVP. We used the isolated tubule perfusion technique to determine the luminal and basolateral effects of AVP on cAMP accumulation separately. A tIMCD was dissected in solution B without collagenase, and then cannulated at both ends. The bath solution was reduced to $100 \mu \mathrm{l}$. The bath and perfusate solutions were nearly identical to dissection solution (solution B), the only exception being that both of the solutions contained $0.5 \mathrm{mM}$ 3-isobutyl-1-methylxanthine (IBMX), a phosphodiesterase inhibitor. The effect of basolateral AVP was measured by adding $50 \mu \mathrm{l}$ of prewarmed $\left(37^{\circ} \mathrm{C}\right)$ solution B containing AVP and $0.5 \mathrm{mM}$ IBMX. The effect of luminal AVP was measured by changing the perfusate to the solution B containing AVP and $0.5 \mathrm{mM}$ IBMX. The bath chamber was placed on a hot plate that was warmed by circulating hot water. After 5 -min incubation at $37^{\circ} \mathrm{C}, 180$ $\mu \mathrm{l}$ of $10 \%$ TCA was added to the bath to stop the reaction and to extract intracellular cAMP. All samples were transferred to $1.5-\mathrm{ml}$ centrifuge tubes. $30 \mu \mathrm{l}$ of distilled water was used to wash the bath and was then added to the samples. Each tube was centrifuged for $5 \mathrm{~min}$ at 3,000 $\mathrm{rpm}$ at $4^{\circ} \mathrm{C}$. $100 \mu$ lof supernatant was stored at $-20^{\circ} \mathrm{C}$ until the assay of cAMP. Blank samples containing medium and TCA were also stored for use as standards in each experiment.

In some studies, we examined the effects of V1a and V2 antagonists and anti-N-3 peptide on AVP-stimulated cAMP accumulation. Isolated tubule perfusion technique was not used in this study. Microdissected tIMCDs were preincubated with the antagonists for $10 \mathrm{~min}$ or with anti$\mathrm{N}-3$ peptide for $15 \mathrm{~min}$ at $37^{\circ} \mathrm{C}$ in $20 \mu$ l solution B with $0.5 \mathrm{mM}$ IBMX. Then, $20 \mu$ l of pre-warmed AVP (final concentration of $10^{-9}$ and $10^{-7}$ $\mathrm{M}$ for V1a and V2 antagonists or $10^{-10} \mathrm{M}$ for the antibody) in the same solution was added. The reaction was terminated after 3-min incubation and cAMP was extracted by the addition of $50 \mu \mathrm{l}$ of ice-cold $10 \%$ TCA. $75 \mu$ l of supernatant was stored.

Determination of cAMP content was performed as described previously $(10,23)$ using radioimmunoassay kit (Amersham Corp.) The recovery of the cAMP added to the bath and processed in the same manner as the sample was $104 \pm 3 \%(n=21)$, and was considered to 
be complete. Therefore, the recovery was not checked in each of the experiments.

Statistics. Results are shown as mean \pm SE. We used Student's $t$ test, analysis of variance followed by the multiple comparison of Dunnet's test, or Kruskal-Wallis's $H$ test with nonparametric comparison with control for statistical analysis. A $P<0.05$ was considered statistically significant.

\section{Results}

Characterization of the antibody. When the antibody was assayed by Western blot analysis with the membrane preparation of inner medulla, it recognized a major band of $62 \mathrm{kD}$ (Fig. 1 ). No bands were observed after the preabsorption of the antibodies with the peptide, or using the preimmune serum. The antibodies did not recognize any bands in the membrane fraction obtained from the rat liver (data not shown). The digestion of the membrane fraction with $\mathrm{N}$-glycanase resulted in a shift of molecular weight from 62 to 36 (Fig. $1 b$ ), which is slightly smaller than its expected molecular weight of 40.5. In the same condition, Na-K-AtPase $\beta$-1 isoform was deglycosylated from 55 to $34 \mathrm{kD}$, showing that the condition was optimal (data not shown).

The antibody did not have V2 antagonistic activity. $10^{-10}$ M AVP-stimulated cAMP accumulation was not different in the presence of the antisera $(\times 500)$ and the preimmune serum ( $\times 500)(247.3 \pm 34.3,157.3 \pm 18.9$, and $171.0 \pm 27.1 \mathrm{fmol} / \mathrm{mm}$ per $3 \mathrm{~min}$, in the presence of AVP alone, AVP plus the preimmune serum, and AVP plus anti-N-3 peptide, respectively, $n$ $=4-8)$.

Immunolocalization of $V 2$ receptor along the nephron. Intensive immunostaining was observed in the medullary and cortical thick ascending limbs (MAL and CAL, respectively), and in the cortical, outer medullary and inner medullary collecting ducts (CCD, OMCD, and IMCD, respectively) (Fig. 2, $a-c$ ). Although all collecting ducts showed heavy staining, only some of MAL and CAL were stained (Fig. $2 b$ ). Proximal tubules showed no staining (Fig. $2 a$ ).

Among collecting ducts, deeper ones showed heavier staining with the increase of principal cells. IMCD showed heaviest staining among nephron segments. Confocal laser-scanning microscopy showed the staining not only in the basolateral membrane but also in the luminal membrane in tIMCD (Fig. 3 $b)$. The staining in the luminal membrane and cytoplasm was granular in tIMCD, whereas the staining in the basolateral membrane was homogeneous and heavy, suggesting that there are fewer V2 receptors in the luminal membrane. Although the luminal staining was not evident in CCD, the staining in the basolateral membrane was also less heavier than that in tIMCD (Fig. $3 a$ ).

Effect of luminal AVP in the absence of bath AVP. In the absence of bath AVP, luminal AVP stimulated cAMP accumulation (Fig. 4). dD-AVP, a V2 agonist, mimicked the effect of AVP. However, the dose-response curve was shifted to the right by two logs when compared with that of bath AVP. Both luminal and basolateral oxytocin $\left(10^{-7} \mathrm{M}\right)$ stimulated cAMP accumulation $(106.0 \pm 22.2$ and $39.9 \pm 15.6 \mathrm{fmol} / \mathrm{mm}$ per $5 \mathrm{~min}, n$ $=4$, respectively). Low $\mathrm{pH}$ in both the bath and luminal fluid also shifted the dose-response curve to the right.

Next, the effects of luminal AVP on Pf and Pu were examined (Fig. 5). Time control experiments showed a decrease of $\mathrm{Pf}$ and $\mathrm{Pu}$ with time in the absence of bath and luminal AVP.
In the presence of $10^{-9} \mathrm{M}$ AVP in the lumen, Pf and Pu were not decreased with time, suggesting a stimulatory effect of luminal AVP on Pf and Pu. $10^{-7} \mathrm{M}$ luminal AVP significantly stimulated Pf. However, the stimulatory effect of luminal AVP on Pf and Pu was much smaller than that of basolateral AVP.

To determine if luminal V2 receptors are independent of basolateral ones, basolateral AVP was administered after the exposure to luminal AVP. Even in the presence of luminal AVP, basolateral AVP further stimulated Pf and Pu (Fig. 6). These data show that luminal AVP occupies luminal but not basolateral V2 receptors. The leak of luminal AVP to the bath is very unlikely.

Effect of luminal AVP in the presence of bath AVP. Effects of luminal AVP on Pf and Pu were examined in the presence of $10^{-9} \mathrm{M}$ bath AVP. Pf and Pu were much higher than when bath AVP was absent. In contrast to its stimulatory effect alone, luminal AVP inhibited bath AVP-stimulated Pf and Pu by $43.7 \%$ and $19.0 \%$, respectively (Fig. 7). The inhibition was greater in $\mathrm{Pf}$ than $\mathrm{Pu}$.

Mechanisms of luminal AVP-induced inhibition of cAMP accumulation. Cyclic AMP is reported to be the second messenger for the V2 action of AVP. We measured cAMP accumulation in the presence of both luminal and basolateral AVP. Addition of luminal AVP decreased bath AVP-stimulated cAMP accumulation by $50 \%$ (Fig. 8). To determine the mechanisms of luminal AVP-induced inhibition of bath AVP-stimulated cAMP accumulation, cAMP accumulation was examined in the presence of V1a and V2 antagonists, and in the presence of an oxytocin agonist and antagonist.

We first studied the effect of V1a and V2 antagonists on bath AVP-stimulated cAMP accumulation. V1a antagonists, OPC21268 , and PTMe-AVP $(14,16)$, did not influence $10^{-7}$ M AVP-stimulated cAMP accumulation (1.5 \pm 5.2 and $-17.0 \pm 10.6 \%$ inhibition, respectively). These two agents inhibited $10^{-9} \mathrm{M}$ AVP-stimulated cAMP accumulation by $29.7 \pm 5.8$ and $80.4 \pm 4.2 \%$, respectively. In contrast, V2 antagonists, OPC-31260 and PTEtV-AVP $(12,17)$, almost abolished the $10^{-9} \mathrm{M}$ AVP-stimulated cAMP accumulation (97.6 \pm 2.4 and $92.5 \pm 1.3 \%$ inhibition, respectively). OPC-31260 also inhibited $10^{-7} \mathrm{M}$ AVP-stimulated cAMP accumulation by $96.6 \pm 0.7 \%$, while PTEtV-AVP inhibited it by only $48.5 \pm 10.1 \%$. These data showed that the two V1a antagonists had slight V2 antagonistic activity at a low concentration of AVP, and that OPC-31260 was a more specific V2 antagonist than PTEtV-AVP.

Addition of the V1a antagonists (OPC 21268 and PTMeAVP) to the lumen with luminal AVP abolished the inhibitory effect of luminal AVP on cAMP accumulation (Fig. 8). In contrast, addition of the V2 antagonists (OPC 31260, and PTEtV-AVP) to the lumen did not alter the luminal effect of AVP. These data suggest that inhibitory effects of luminal AVP may be mediated by V1a receptors. However, these V1a antagonists are known to antagonize oxytocin receptors to a lesser extent. Therefore, we used a selective oxytocin antagonist and an agonist to determine if oxytocin receptors participate in the luminal action of AVP. When $10^{-6} \mathrm{M}$ GN-OVT, a selective oxytocin antagonist (15), was in the lumen together with AVP, the effect of luminal AVP was inhibited (Fig. 8). A selective oxytocin agonist in the lumen, tg-OXT (13), mimicked the luminal effect of AVP on cAMP accumulation (Fig. 8).

Dose-response curve of luminal AVP on basolateral AVPstimulated Pf. In this series of experiments, a lower dose of 

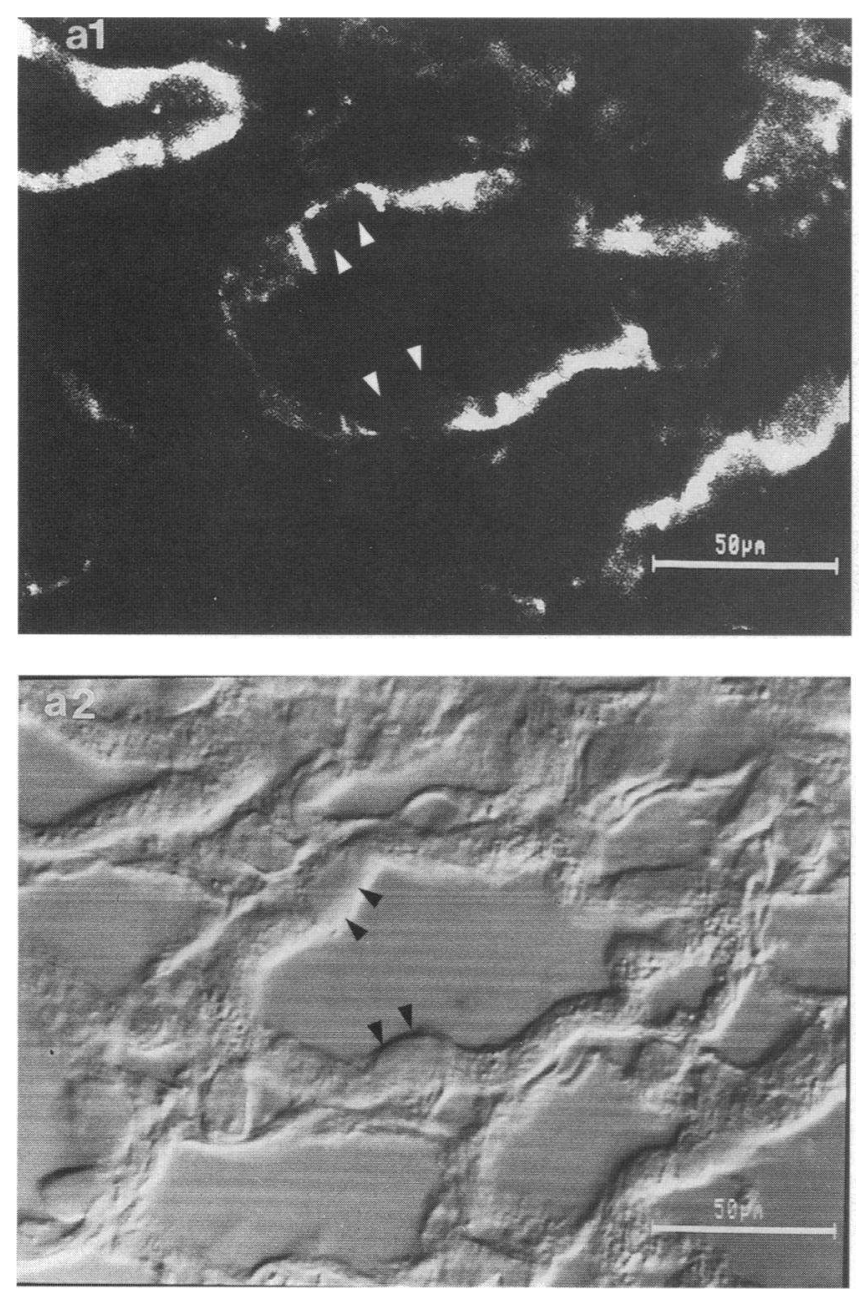

Figure 3. Intracellular localization of V2 receptor in CCD and tIMCD. Sections incubated with the antisera (IgG fraction, $\times 500)$ and FITCconjugated goat-anti-rabbit $\operatorname{IgG} F\left(a b^{\prime}\right) 2$ were observed with confocal laser-scanning microscope. $(a l)$ The staining was heavier in the basolateral membrane than the luminal membrane $(\Delta)$ in the principal cells (CCD). (a2) The photograph of the same field without fluorescence showed the intact luminal and basolateral membrane $(\Delta)$. (bl) The granular staining was seen in the luminal membrane $(\Delta)$ and cytoplasm while there was heavy staining of the basolateral membrane in IMCD cells (tIMCD). (b2) Another tIMCD cell showed the same pattern of the staining. (b3). No staining of tIMCD was observed with preimmune serum $(\times 500)$.

AVP, $10^{-11} \mathrm{M}$, was used in the bath. $10^{-11} \mathrm{M}$ luminal AVP decreased $10^{-11} \mathrm{M}$ bath AVP-stimulated Pf by $22.5 \pm 8.3 \%$, whereas the vehicle in the lumen did not change $\mathrm{Pf}$ ( $+2.7 \pm 6.3 \%, n=5, P>0.05$, Fig. 9). A higher dose of AVP and $10^{-9} \mathrm{M}$ luminal AVP, reduced $10^{-11} \mathrm{M}$ bath AVPstimulated Pf by $63.2 \pm 13.1 \%(n=4, P<0.02) .10^{-7} \mathrm{M}$ tgOXT, a selective oxytocin agonist, mimicked luminal AVP and decreased Pf by $22.5 \pm 4.4 \%$ (from $212.7 \pm 31.0$ to $164.5 \pm 23.4$ $\mu \mathrm{m} / \mathrm{s}, n=4, P<0.02$ ).
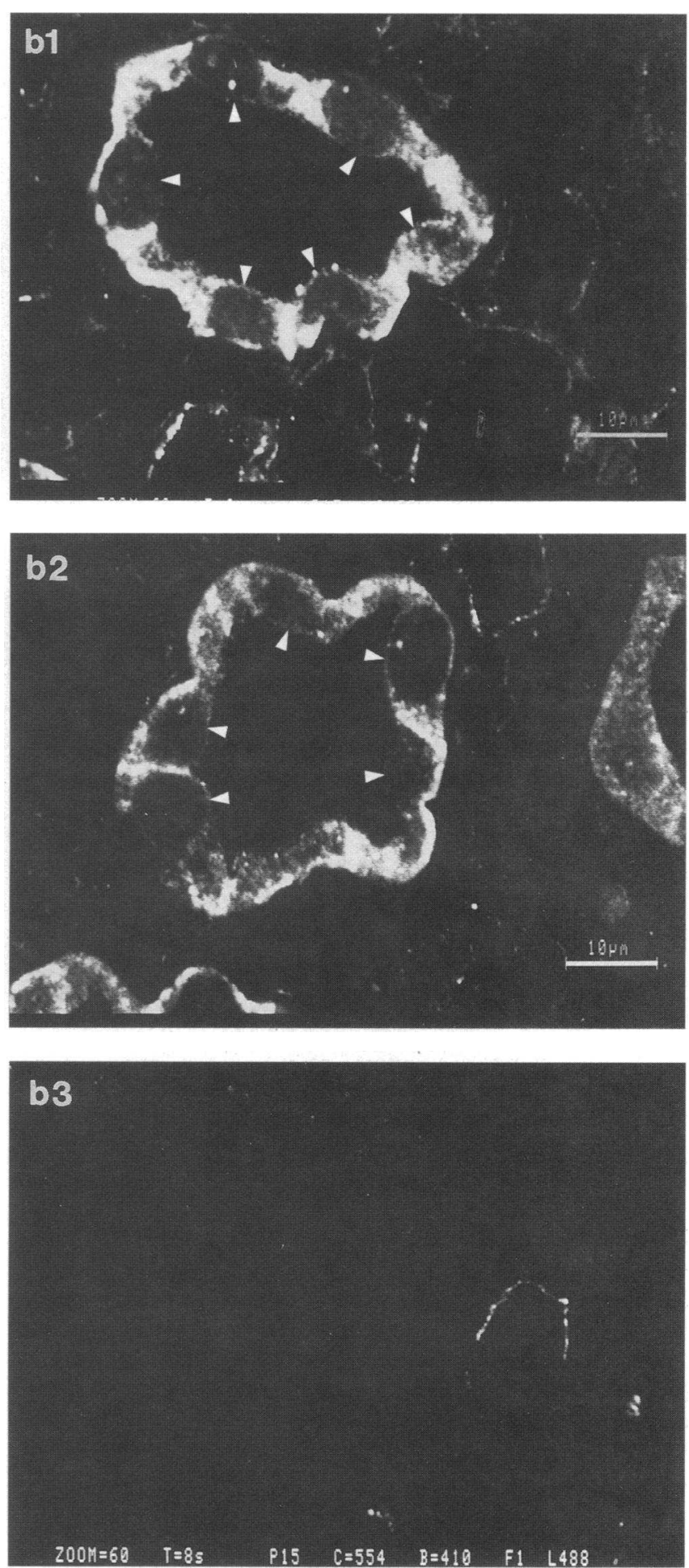

Effect of VIa, V2, and oxytocin antagonists on Pf. Next, we examined the effect of V1a, V2, and oxytocin antagonists on AVP-stimulated Pf. Luminal AVP $\left(10^{-9} \mathrm{M}\right)$ inhibited $10^{-11}$ $M$ bath AVP-stimulated Pf from $164.3 \pm 37.2$ to $56.4 \pm 23.7 \mu \mathrm{m} /$ $\mathrm{s}(n=4, P<0.02)$. Luminal AVP $\left(10^{-9} \mathrm{M}\right)$ did not inhibit basolateral AVP $\left(10^{-11} \mathrm{M}\right)$-stimulated Pf in the presence of a V1a antagonist, $10^{-7} \mathrm{M}$ PTMe-AVP (from 256.9 \pm 56.6 to $212.0 \pm 37.9 \mu \mathrm{m} / \mathrm{s}, n=5, P>0.05)$, or V2 antagonists, $10^{-7}$ M PTEtV-AVP or $5 \times 10^{-7} \mathrm{M}$ OPC 31260 , in the lumen (from 


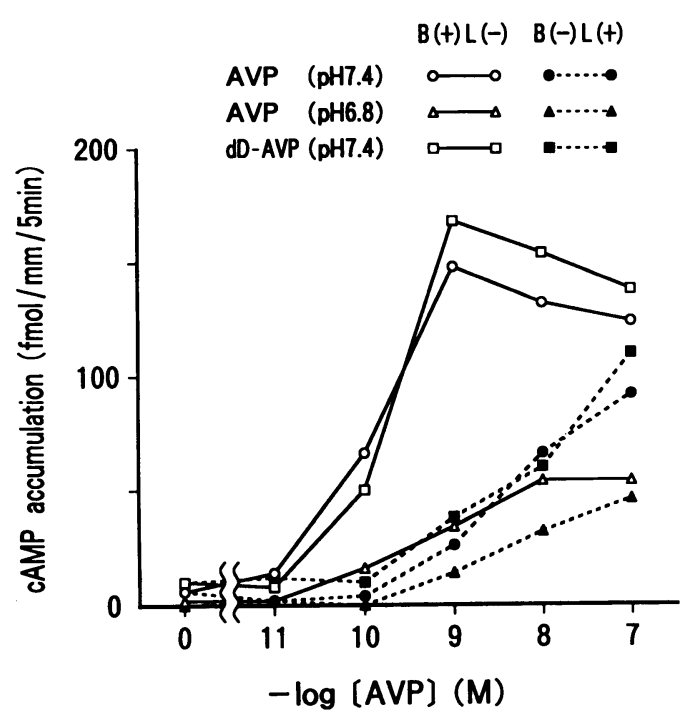

Figure 4. Effect of luminal or basolateral AVP or dD-AVP on cAMP accumulation in IMCD. AVP or AD-AVP was added only to the bath solution or perfusate. When AVP in a solution of $\mathrm{pH} 6.8$ was administered to the bath or perfusate, the $\mathrm{pH}$ of the solution on the other side of the membrane was 7.4. Thus, the effect of low $\mathrm{pH}$ was tested on only one side of the membrane. The values are the mean of 4 to 27 measurements. $(B(+) L(-))$ only in the bath; $(B(-) L(+))$ only in the perfusate.

$189.9 \pm 88.5$ to $195.6 \pm 96.9 \mu \mathrm{m} / \mathrm{s}, n=4, P>0.05$, and from $237.6 \pm 60.1$ to $203.0 \pm 47.5 \mu \mathrm{m} / \mathrm{s}, n=4, P>0.05$, in the presence of PTEtV-AVP and OPC 31260, respectively, Fig. 10). When $10^{-7} \mathrm{M}$ GN-OVT, a selective oxytocin antagonist, was present in the lumen, addition of $10^{-9} \mathrm{M}$ AVP in the lumen did not change Pf (from $190.4 \pm 53.5$ to $166.0 \pm 42.6 \mu \mathrm{m} / \mathrm{s}, n$ $=5, P>0.05$ ).

\section{Discussion}

The present study shows that V2 receptor is localized in some of thick ascending limbs and all of principal and IMCD cells. There were few luminal V2 receptors as well as dense basolateral $\mathrm{V} 2$ receptors in the collecting ducts. The presence of $\mathrm{V} 2$ receptor in the luminal membrane of tIMCD was confirmed by the stimulation of cAMP accumulation, Pf, and Pu by luminal AVP in the absence of basolateral AVP. In contrast, luminal AVP inhibited the action of basolateral AVP by decreasing cAMP accumulation through V1a or oxytocin receptors and by an unknown mechanism through $\mathrm{V} 2$ receptors in the luminal membrane of tIMCD in the presence of basolateral AVP. Thus, AVP is thought to act from both the basolateral side and the luminal side to regulate water and urea transport in tIMCD.

The predicted size of the V2 receptor from its sequence is $\sim 40.5 \mathrm{kD}(9)$. Our immunoblot analysis showed the band of $\mathrm{V} 2$ receptor at $62 \mathrm{kD}$. Since we used strongly reduced conditions for SDS-PAGE, the size of V2 receptor is not overestimated. Although only one putative $\mathrm{N}$-linked glycosylation site was considered from its amino acid sequences, the digestion of the membrane with $\mathrm{N}$-glycanase resulted in a decrease of molecular mass from 62 to $36 \mathrm{kD}$, suggesting a large glycosylation of the receptor. The role of such a large glycosylation has to be examined further.
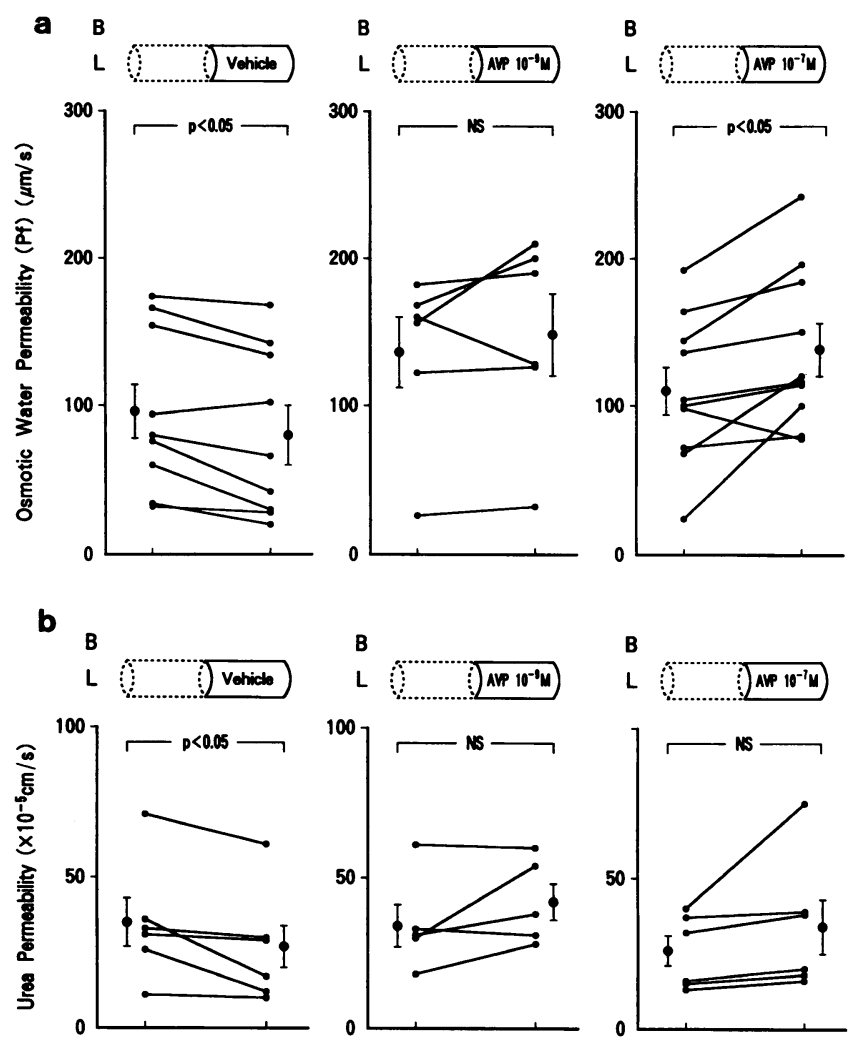

Figure 5. Effect of luminal AVP on Pf $(a)$ and Pu $(b)$ in IMCD. (a) AVP or vehicle was added only to the perfusate. The decrease of Pf with time was blocked by $10^{-9} \mathrm{M}$ luminal AVP. $10^{-7} \mathrm{M}$ AVP stimulated Pf by $25 \%$. (b) Luminal AVP abolished the decrease of Pu with time, showing the stimulatory effect of luminal AVP on $\mathrm{Pu}$. B, bath; L, lumen (perfusate).

Our immunohistochemical data of the localization of V2 receptor along the nephron are quite compatible with previous reports that used different methods $(4-6,10,24)$. Only some of CAL and MAL were stained, suggesting the heterogenious localization in thick ascending limbs. We have reported that AVP-stimulated cAMP accumulation was significantly higher in long-looped MAL than short-looped MAL (23). The kinds of subgroups that do not have $\mathrm{V} 2$ receptors must be ascertained. In collecting ducts, the staining was increased in deeper ones with the increase of principal cells. The presence of luminal V2 receptor was most evident in tIMCD. Since principal cells and IMCD cells belongs almost same cell types, principal cells would have luminal V2 receptors as well as IMCD cells.

The physiological concentration of plasma AVP is $\sim 0.5$ $\times 10^{-12}$ to $10^{-11} \mathrm{M}(0.5-10 \mathrm{pg} / \mathrm{ml})$, whereas that of urinary AVP is $10^{-11}$ to $10^{-9} \mathrm{M}(25-27)$. Thus, the urinary concentration of AVP is 10-100 times higher than that of plasma. Since plasma concentration of AVP is relatively stable, changes in AVP concentration are much larger in urine than in plasma. These findings suggest that urinary AVP concentration may be as important as plasma AVP for day-to-day urine concentration. Our data showed that equal concentrations of luminal AVP to basolateral AVP inhibited basolateral AVP-stimulated Pf by $30-40 \% \cdot 10^{-9} \mathrm{M}$ luminal AVP inhibited $10^{-11} \mathrm{M}$ bath AVPstimulated $\mathrm{Pf}$ by $65 \%$. The latter experimental condition is thought to be close to the normal physiological condition, suggesting that the basolateral action of AVP is suppressed by 

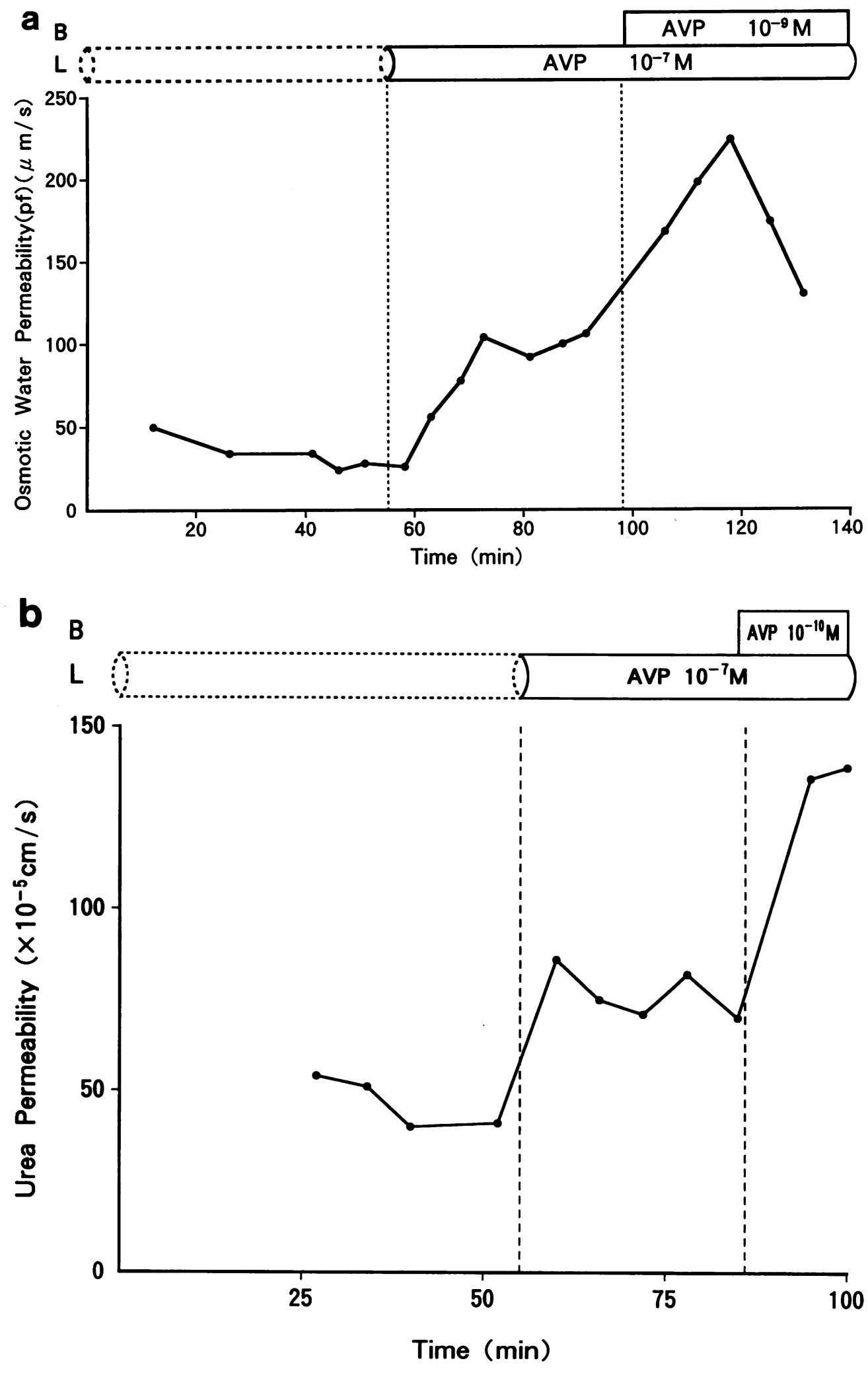

Figure 6. Effect of basolateral AVP on luminal AVP-stimulated $\mathrm{Pf}(a)$ and $\mathrm{Pu}(b)$ in IMCD. $(a)$ After washing out intrinsic AVP, $\operatorname{AVP}\left(10^{-7} \mathrm{M}\right)$ was added initially to the lumen and then to the bath. Luminal AVP-stimulated Pf and bath AVP further stimulated Pf even in the presence of luminal AVP. (b) After Pu became stable, AVP was added initially to the lumen and then to the bath. Basolateral AVP stimulated Pu even after the stimulation by luminal AVP. Both results demonstrated the presence of independent $\mathrm{V} 2$ receptors in the luminal and basolateral membrane.

luminal AVP by at least half under normal physiological conditions. It is quite an interesting phenomenon that AVP action is controlled by AVP itself. The source of urinary AVP is plasma. Urinary excretion of AVP was $36.3 \pm 7.9 \mathrm{ng} / \mathrm{d}$ in normal subjects, showing that a large amount of AVP is excreted into urine every day (27). Our data suggest that urinary excretion of AVP, working as a negative feedback system for the basolateral action of plasma AVP, is important in maintaining body fluid homeostasis.

IMCD cells are polarized so that the characteristics of luminal and basolateral membrane are different. For many years, AVP receptors were thought to be localized only in the basolat- 

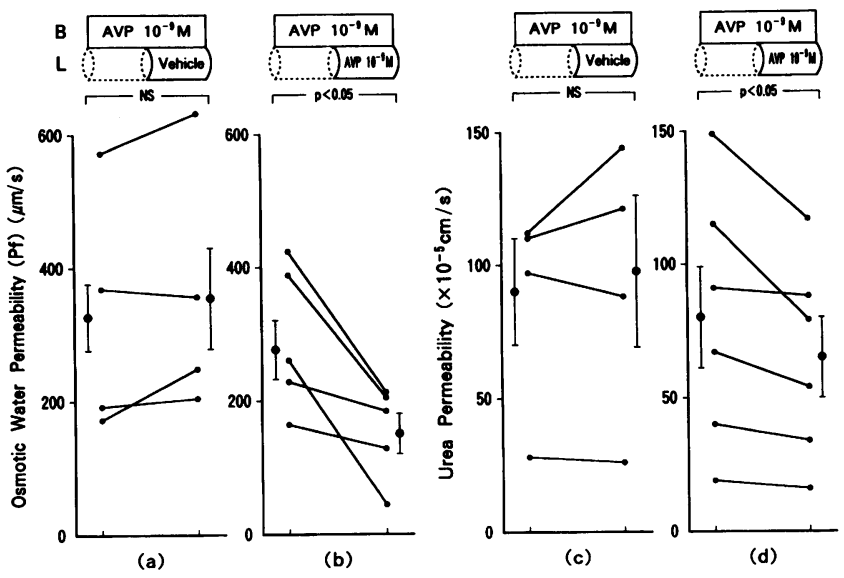

Figure 7. Effect of luminal AVP on bath AVP-stimulated Pf and Pu in IMCD. Microdissected IMCD was perfused in the presence of bath AVP. After control collection, AVP or vehicle was added to the perfusate. Luminal AVP inhibited basolateral AVP-stimulated Pf and Pu, while luminal vehicle showed no effects.

eral membrane. Although the possibility of the luminal AVP receptor was first described by Castel in distal convoluted tubules and collecting ducts, extensive studies were not performed (28). Ando et al. showed a luminal action of AVP in CCD, thought to be only through $\mathrm{V} 1 \mathrm{a}$ receptors and not $\mathrm{V} 2$ receptors (6). We demonstrated the presence of V2 receptors in both the luminal and basolateral membranes of tIMCDs by two methods: immunohistochemical and physiological studies. The lower cAMP accumulation after luminal AVP administration compared with basolateral AVP stimulation suggests low receptor density in the luminal membrane, which is compatible with the granular labeling of the luminal membrane and dense labeling of the basolateral membrane. Thus, tIMCD is unique among the nephron segments in the intracellular localization of V2 receptors. Since tIMCD is the last segment of the nephron, V2

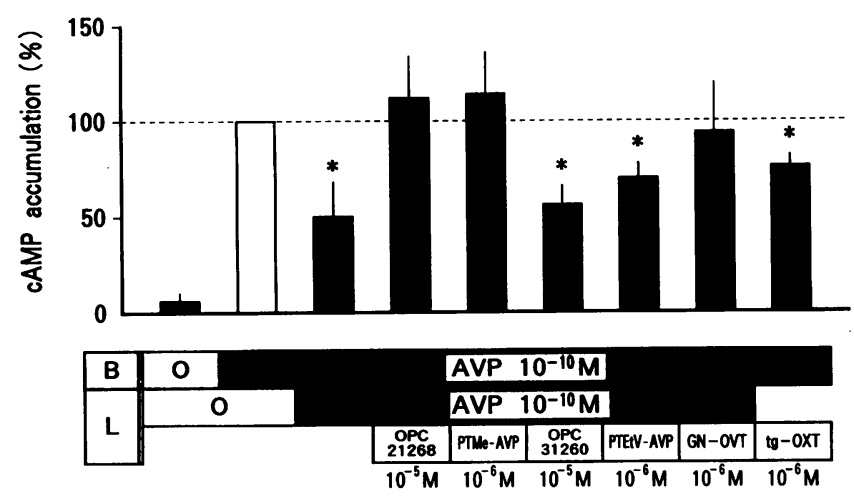

Figure 8. Effect of luminal V1a or V2 antagonists and a selective oxytocin agonist or antagonist on AVP-stimulated cAMP accumulation. Agents were administered only to the perfusate. cAMP accumulation was measured after 5-min incubation. Control value was considered to be $100 \%$. The values are the mean of 4-10 experiments. Luminal AVPinduced inhibition of bath AVP-stimulated cAMP accumulation was abolished by luminal Vla antagonists (OPC 21268 and PTMe-AVP) and an oxytocin antagonist (GN-OVT), but not by luminal V2 antagonists (OPC 31260 and PTEtV-AVP), and was mimicked with an oxytocin agonist $(\operatorname{tg}-O X T)$.

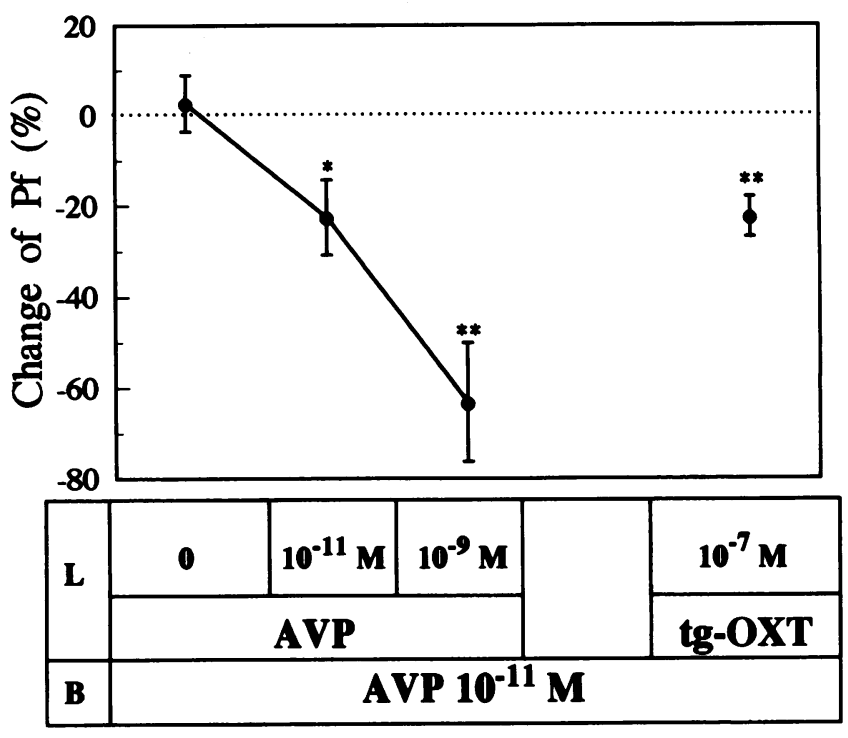

Figure 9. Dose response curve of luminal AVP for inhibiting basolateral AVP-stimulated Pf. The changes of Pf from control to experimental period are shown by percentage. Increase of luminal concentration of AVP caused a increase in inhibition of basolateral AVP-stimulated Pf. $10^{-7} \mathrm{M}$ tg-OXT mimicked luminal AVP and showed almost same inhibition with $10^{-11} \mathrm{M}$ luminal AVP.

receptors in the lumen may exist heavier than CCD for more complete and final regulation of water and sodium excretion.

Luminal AVP stimulated Pf and Pu in the absence of basolateral AVP, although this is not physiologic. In the physiologic condition, i.e., in the presence of basolateral AVP, luminal AVP inhibited the basolateral action of AVP. The luminal effects of AVP on Pf and cAMP accumulation were blocked by a V1a antagonist, PTMe-AVP, and by an oxytocin antagonist, GNOVT, and mimicked by an oxytocin agonist, tg-OXT. Therefore, a part of this inhibitory effect is mediated by the decrease in basolateral AVP-stimulated cAMP accumulation by luminal AVP through the occupancy of Vla or oxytocin receptors. Teitelbaum reported that AVP and V2 receptor agonist stimulated phosphoinositide hydrolysis via occupancy of oxytocin receptors in cultured IMCD cells (29). Han and colleagues showed that high concentration $\left(10^{-8} \mathrm{M}\right)$ of AVP inhibited low dose $\left(10^{-10} \mathrm{M}\right)$ AVP-stimulated water permeability in IMCD through oxytocin receptor or a novel vasopressin receptor (30). Oxytocin itself stimulated water permeability (30). Our data of isolated perfusion study suggest the presence of V1a or oxytocin receptors in the luminal membrane of IMCD. Although luminal V2 antagonists did not inhibit the basolateral AVP-stimulated cAMP accumulation, they inhibited basolateral AVP-stimulated Pf. Thus, the occupancy of luminal V2 receptors can cause the inhibition of basolateral action of AVP by an unknown mechanism.

Receptor-ligand complexes are internalized by endocytosis $(31,32)$. There are several types of receptor recycling $(33$, $34)$. Receptors in the basolateral membrane are recycled to basolateral membrane in polarized cells such as IMCDs. Our data show the presence of V2 receptors not only in the basolateral, but also in the luminal membrane. Nothing is known about the internalization and recycling of V2 receptor in the luminal membrane. There could be a new type of receptor recycling. One of the possible explanations of internalization and recycling 

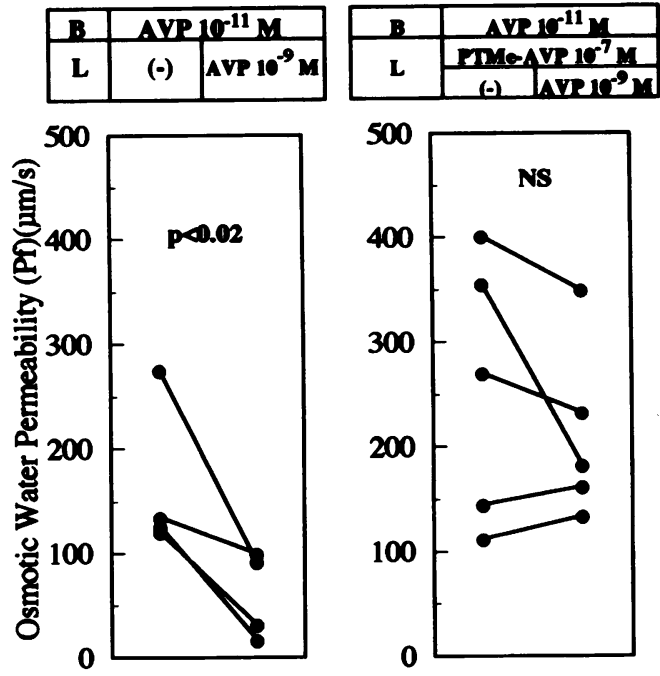

(a)

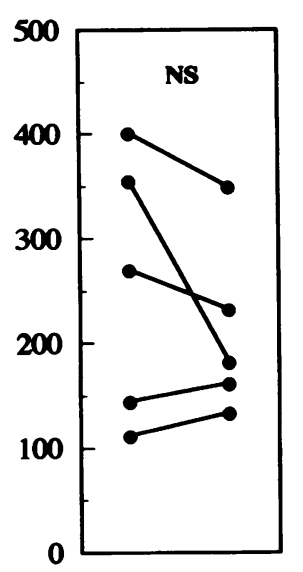

(b)
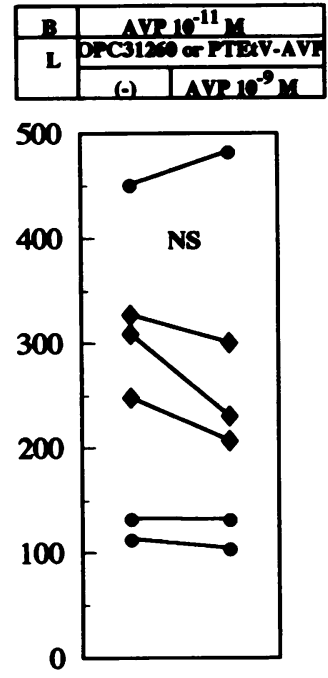

(c)
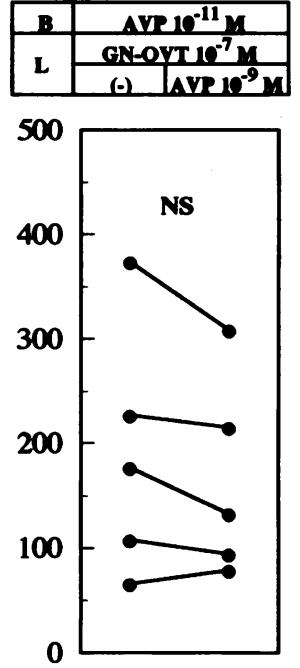

(d)
Figure 10. Effect of luminal V1a, $\mathrm{V} 2$, or oxytocin antagonist on bath AVP-stimulated Pf in IMCD. Luminal administration of $10^{-7} \mathrm{M}$ PTMe-AVP (V1a antagonist, $b$ ), $10^{-7} \mathrm{M}$ PTEtV-AVP (V2 antagonist, $\bullet$ in $c), 5 \times 10^{-7} \mathrm{M}$ OPC 31260 (V2 antagonist, $\bullet$ in $c$ ), and $10^{-7} \mathrm{M}$ GN-OVT (oxytocin antagonist, $d$ ) abolished luminal effects of $10^{-9} \mathrm{M} \operatorname{AVP}(a)$. of $\mathrm{V} 2$ receptor in the luminal membrane is transcytosis (34). Monometric immunoglobulin is transported from proximal small intestine (apical membrane) into the circulation (basolateral membrane). Internalization and recycling of V1a receptors have been observed in rat hepatocytes and vascular smooth muscle cells (35-37). Internalization of V2 receptors in the basolateral membrane has also been exhibited (38). AVP-V2 receptor complex must also be internalized from the luminal membrane. The presence of $\mathrm{V} 2$ receptors in the luminal membrane of tIMCD raises the possibility of transcytosis of AVP from luminal membrane to basolateral membrane or vice versa. Further studies are needed to determine the mechanisms of internalization and recycling of $\mathrm{V} 2$ receptor in the luminal membrane of IMCDs.

The cAMP system is controlled by the protein kinase C system. Teitelbaum reported that occupancy of oxytocin receptors by AVP stimulated phosphoinositide hydrolysis without affecting cAMP accumulation (29). Teitelbaum et al. also reported that AVP stimulated phopholipase $C$ in cultured IMCD cells (39). Endothelin-1 is known to reduce AVP-induced cAMP accumulation by stimulating protein kinase C (40). A similar stimulation of protein kinase $C$ is a likely explanation for oxytocin or V1a receptor-mediated inhibition of CAMP accumulation by luminal AVP.

In summary, our data show that V2 receptors are localized in some of thick ascending limb cells and all of principal and IMCD cells. Not only the heavy staining of the basolateral membrane but slight staining of the luminal membrane was observed in collecting ducts, especially in IIMCD, where luminal AVP inhibits basolateral AVP-stimulated water and urea permeability. This effect is mediated by the decrease of basolateral AVP-induced cAMP accumulation by luminal AVP via the occupancy of luminal V1a or oxytocin receptors and by an unknown mechamism via $\mathrm{V} 2$ receptors.

\section{Acknowledgments}

We thank Drs. Mark A. Knepper (National Institutes of Health, Bethesda, MD), Robert A. Star (University of Texas Southwestern Medical Center, Dallas, TX), and Jeff M. Sands (Emory University, Atlanta, GA), for their critical reading of the manuscript. We also thank
Dr. Mark A. Knepper for affinity purification of the antibody. We thank Dr. Soren Nielsen (University of Aarhus, Denmark) for his useful suggestions for immunohistochemical studies. We also thank Dr. Maurice Manning (University of Ohio, Toledo, $\mathrm{OH}$ ) and Otsuka Pharmaceutical Co. for giving us oxytocin, V1a, and V2 antagonists.

This study was supported by a Grant-in-Aid for Scientific Research from the Ministry of Education, Science and Culture in Japan $(04454234,04670383$, and 06671133$)$ and a Grant-in-Aid for the Development of Scientific Research (B1, 05557053, and 05557054).

\section{References}

1. Knepper, M. A., and F. C. Rector, Jr. 1991. Urinary concentration and dilution. In The Kidney B. M. Brenner and F. C. Rector, Jr., editors. W. B. Saunders, Philadelphia, 445-482.

2. Michell, R. H., C. J. Kirk, and M. M. Billah. 1979. Hormonal regulation of phosphatidylinositol breakdown, with particular reference to the hepatic effects of vasopressin. Biochem. Soc. Trans. 7:861-867.

3. Phillips, P. A., J. M. Abrahams, J. M. Kelly, V. Mooser, D. Trinder, and C. I. Johonston. 1990. Localization of vasopressin binding sites in rat tissues using specific V1 and V2 selective ligands. Endocrinology. 126:1478-1484.

4. Grantham, J. J., and M. B. Burg. 1966. Effect of vasopressin and cAMP on permeability of isolated collecting tubules. Am. J. Physiol. 211:255-259.

5. Morel, F. 1981. Sites of hormone action in the mammalian nephron. Am. J. Physiol. 240(Renal Fluid Electrolyte Physiol. 9):F159-F164.

6. Ando, Y., K. Tabei, and Y. Asano. 1991. Luminal vasopressin modulates transport in the rabbit cortical collecting duct. J. Clin. Invest. 88:952-959.

7. Moses, A., and E. Steciak. 1986. Urinary and metabolic clearance of arginine vasopressin in normal subjects. Am. J. Physiol. 251(Regulatory Integrative Comp. Physiol. 20):R365-R370.

8. Morel, A., A.-M. O'Carroll, M. J. Brownstein, and S. J. Lolait. 1993. Molecular cloning and expression of a rat $\mathrm{Vla}$ arginine vasopressin receptor. Nature (Lond.). 356:523-526.

9. Lolait, S. J., A.-M. O'Carroll, O. W. McBride, M. Konig, A. Morel, and M. J. Brownstein. 1992. Cloning and characterization of a vasopressin V2 receptor and possible link to nephrogenic diabetes insipidus. Nature (Lond.). 357:336339.

10. Nonoguchi, H., M. A. Knepper, and V. C. Manganiello. 1987. Effects of atrial natriuretic factor on cyclic guanosine monophosphate and cyclic adenosine monophosphate accumulation in microdissected nephron segments from rats. $J$. Clin. Invest. 79:500-507.

11. Sands, J. M., H. Nonoguchi, and M. A. Knepper. 1987. Vasopressin effects on urea and $\mathrm{H}_{2} \mathrm{O}$ transport in inner medullary collecting ducts. Am. J. Physiol. 253(Renal Fluid Electrolyte Physiol. 22):F823-F832.

12. Sawyer, W. H., P. K. T. Pang, J. Seto, M. McEnroe, B. Lammek, and M. Manning. 1981. Vasopressin analogs that antagonize antidiuretic responses by rats to the antidiuretic hormone. Science (Wash. DC). 212:49-51.

13. Lowbridge, J., and M. Manning. 1977. Synthesis and some pharmacological properties of [4-Threonine, 7-glycine] oxytocin, [1-9L-2-Hydroxy-3-mercaptopropanoic acid),4-threonine,7-glycine ]oxytocin (Hydroxy $\left[\mathrm{Thr}^{4}, \mathrm{Gly}^{7}\right]$ oxytocin), 
and [7-Glycine] oxytocin, peptides with high oxytocic-antidiuretic selectivity. $J$. Med. Chem. 20:120-123.

14. Kruszynski, M., B. Lammek, and M. Manning. 1980. [ 1- ( $\beta$-mercapto- $\beta, \beta$ cyclopentamethylenepropionic acid),2-(O-methyl)tyrosine ] arginine-vasopressin and [1-( $\beta$-mercapto- $\beta, \beta$-cyclopentamethylenepropionic acid $)]$ arginine-vasopressin, two highly potent antagonists of vasopressor response to arginine-vasopressin. J. Med. Chem. 23:364-368.

15. Manning, M., M. Kruszynski, K. Bankowski, A. Olma, B. Lammek, L. L. Cheng, W. A. Klis, J. Seto, J. Hadler, and W. H. Sawyer. 1989. Solid-phase synthesis of 16 potent (selective and nonselective) in vivo antagonists of oxytocin J. Med. Chem. 32:382-391.

16. Yamamura, Y., H. Ogawa, T. Chihara, K. Kondo, T. Onogawa, S. Nakamura, T. Mori, M. Tominaga, and Y. Yabuuchi. 1991. OPC-21268, an orally effective, nonpeptide vasopressin V1 receptor antagonist. Science (Wash. DC) 252:572-574.

17. Yamamura, Y., H. Ogawa, H. Yamashita, T. Chihara, H. Miyamoto, S. Nakamura, T. Onogawa, T. Yamashita, T. Hosokawa, T. Mori, et al. 1992 Characterization of a novel aquaretic agent, OPC-31260, as an orally effective nonpeptide vasopressin $\mathrm{V}_{2}$ receptor antagonist. Br. J. Pharmacol. 105:787-791.

18. Tarentino, A. L., C. M. Gomez, and T. H. Plummer, Jr. 1985. Deglycosylation of asparagine-linked glycans by peptide:N-glycosidase F. Biochemistry. 24:4665-4671.

19. Laemmli, U. K. 1970. Cleavage of structural protein during the assembly of the head of bacteriophage T4. Nature (Lond.). 227:680-685.

20. Nonoguchi, H., J. M. Sands, and M. A. Knepper. 1988. Atrial natriuretic factor inhibits vasopressin-stimulated osmotic water permeability in rat inner medullary collecting duct. J. Clin. Invest. 82:1383-1390.

21. Oishi, R., H. Nonoguchi, K. Tomita, and F. Marumo. 1991. Endothelin1 inhibits AVP-stimulated osmotic water permeability in rat inner medullary collecting duct. Am. J. Physiol. 261(Renal Fluid Electrolyte Phsiol. 30):F951F956.

22. Al-Zahid, G., J. A. Schafer, S. L. Troutman, and T. E. Andreli. 1977. The effect of antidiuretic hormone on water and solute permeation, and the activation energies for these precesses, in mammalian cortical collecting tubules: evidence for parallel $\mathrm{ADH}$-sensitive pathways for water and solute diffusion in luminal plasma membranes. J. Membr. Biol. 31:103-130.

23. Nonoguchi, H., K. Tomita, and F. Marumo. 1992. Effects of atrial natriuretic peptide and vasopressin on chloride transport in long- and short-looped medullary thick ascending limbs. J. Clin. Invest. 90:349-357.

24. Ostrowski, N. L., W. S. Young III, M. A. Knepper, and S. J. Lolait. 1993. Expression of vasopressin V1a and V2 receptor messenger ribonucleic acid in the liver and kidney of embryonic, developing, and adult rats. Endocrinology. 133:1849-1859.
25. Robertson, G. L. 1977. The regulation of vasopressin function in health and disease. Recent Prog. Horm. Res. 63:6-13.

26. Fressinaud, P., P. Corvol, and J. Menard. 1974. Radioimmunoassay of urinary antidiuretic hormone in man: stimulation-suppression tests. Kidney Int 6:184-190.

27. Pruszczynski, W., H. Caillens, L. Drieu, L. Moulonguet-Doleris, and R. Ardaillou. 1984. Renal excretion of antidiuretic hormone in healthy subjects and patients with renal failure. Clin. Sci. 67:307-312.

28. Castel, M. 1978. Immunocytochemical evidence for vasopressin receptors. J. Histochem. Cytochem. 26:229a. (Abstract.)

29. Teitelbaum, I. 1991. Vasopressin-stimulated phosphoinositide hydrolysis in cultured rat inner medullary collecting duct cells is mediated by the oxytocin receptor. J. Clin. Invest. 87:2122-2126.

30. Han, J. S., Y. Maeda, and M. A. Knepper. 1993. Dual actions of vasopressin and oxytocin in regulation of water permeability in terminal collecting duct. Am. J. Physiol. 265(Renal Fluid Electrolyte Physiol.34):F26-F34.

31. Goldstein, J. L., R. G. W. Anderson, and M. S. Brown. 1979. Coated pits, coated vesicles, and receptor-mediated endocytosis. Nature (Lond.). 279:679685.

32. Lutz, W., J. L. Salisbury, and R. Kumar. 1991. Vasopressin receptormediated endocytosis: current view. Am. J. Physiol. 261(Renal Fluid Electrolyte Physiol. 30):F1-F13.

33. Brown, M. S., R. G. W. Anderson, and J. L. Goldstein. 1983. Recycling receptors: the round-trip itinerary of migrant membrane proteins. Cell. 32:663667.

34. Mostov, K. E., and N. E. Simister. 1985. Transcytosis. Cell. 43:389-390.

35. Fishman, J. B. B. F. Dickey, N. L. R. Bucher, and R. E. Fine. 1985. Internalization, recycling, and redistribution of vasopressin receptors in rat hepatocytes. J. Biol. Chem. 260:12641-12646.

36. Briner, V. A., B. Williams, P. Tsai, and R. W. Schrier. 1992. Demonstration of processing and recycling of biologically active $\mathrm{V} 1$ vasopressin receptors in vascular smooth muscle. Proc. Natl. Acad. Sci. USA. 89:2854-2858.

37. Lutz, W., M. Sanders, J. Salisbury, and R. Kumar. 1990. Internalization of vasopressin analogs in kidney and smooth muscle cells: evidence for receptormediated endocytosis in cells with V2 or V1 receptors. Proc. Natl. Acad. Sci. USA. 87:6507-6511.

38. Kirk, K. L. 1988. Binding and internalization of a fluorescent vasopressin analogue by collecting duct cells. Am. J. Physiol. 255(Cell Physiol. 24):C622C632.

39. Teiterbaum, I., and A. Strasheim. 1990. AVP stimulates adenylyl cyclase and phospholipase $\mathrm{C}$ in reciprocal fashion in cultured RIMCT cells. Am. J. Physiol. 259(Cell Physiol. 28):C693-C696.

40. Tomita, K., H. Nonoguchi, and F. Marumo. 1990. Effects of endothelin on peptide-dependent cyclic adenosine monophosphate accumulation along the nephron segments of the rat. J. Clin. Invest. 85:2014-2018. 